
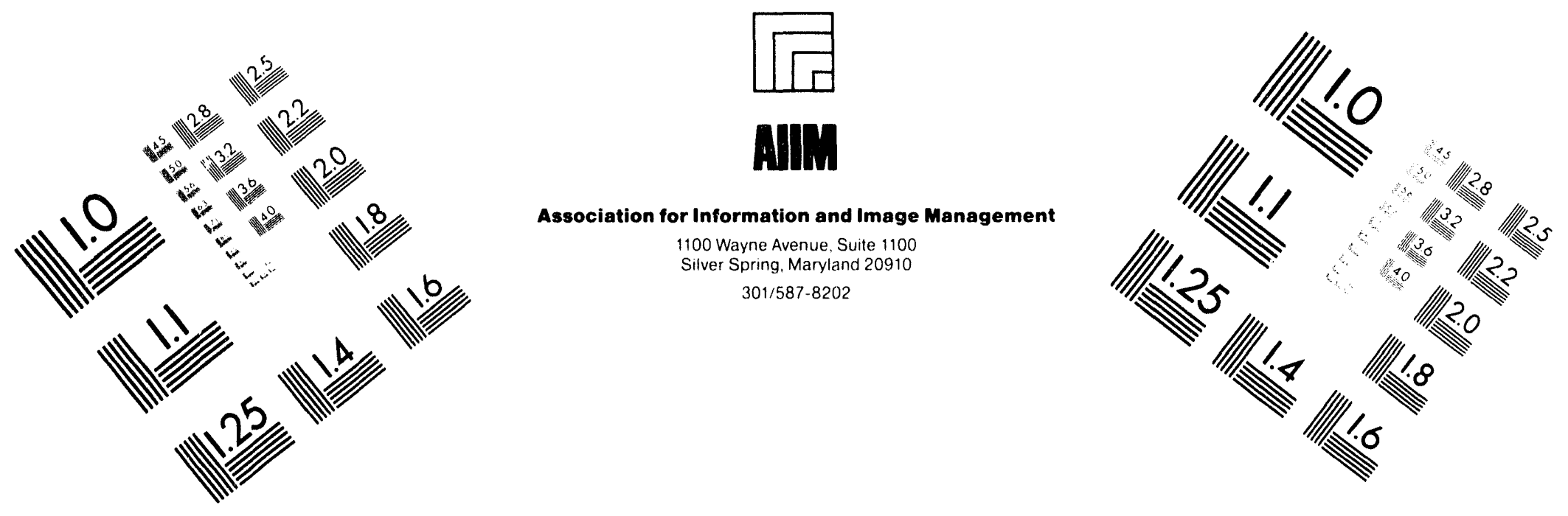

\title{
Centimeter
}

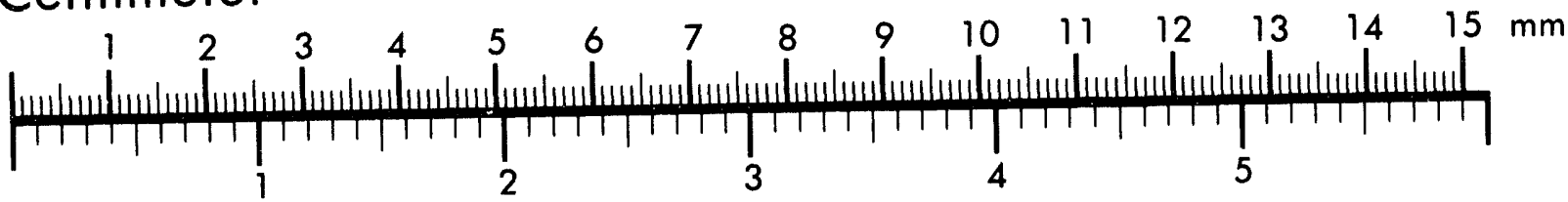
Inches
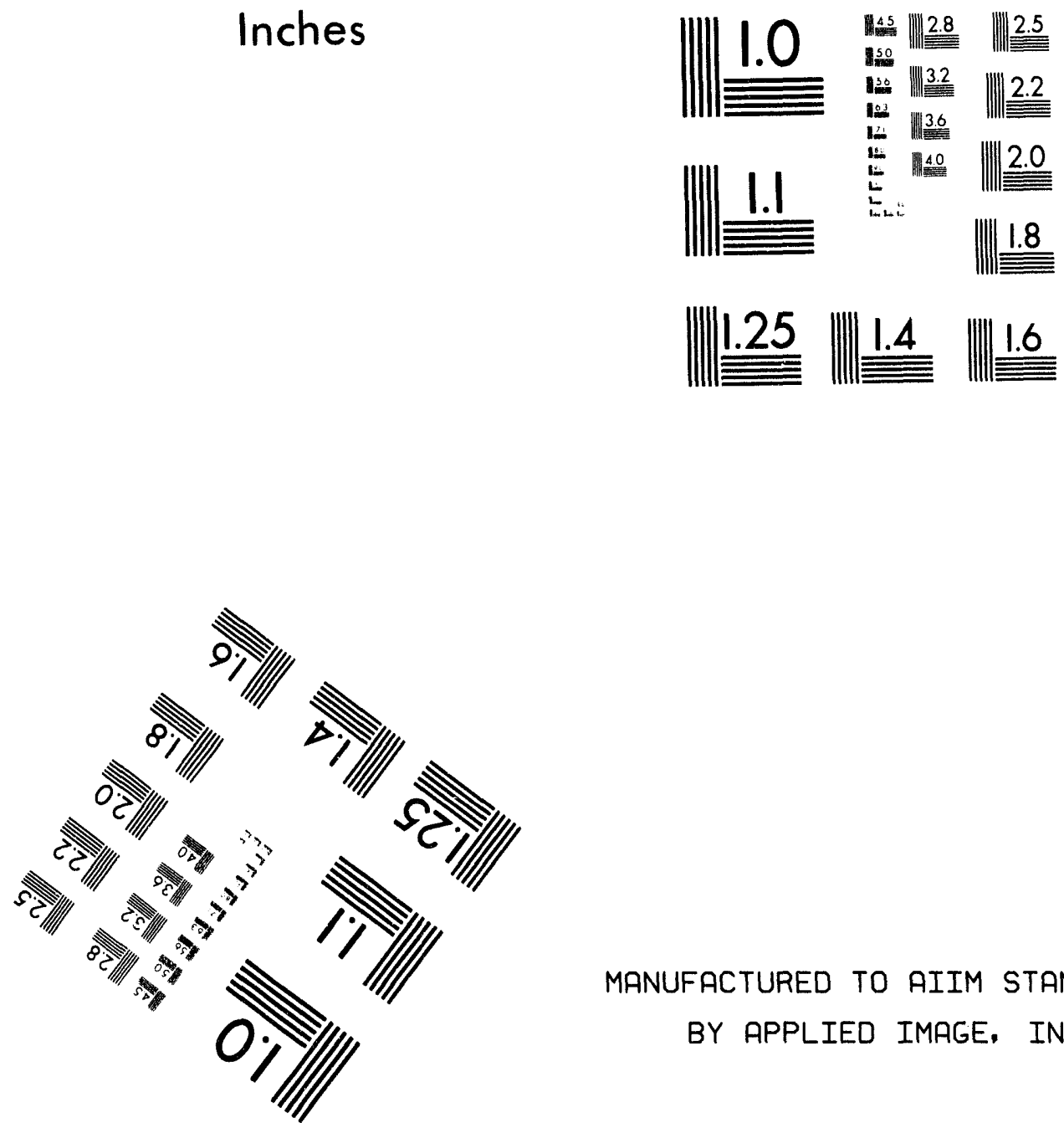

MANUFACTURED TO AIIM STANDARDS

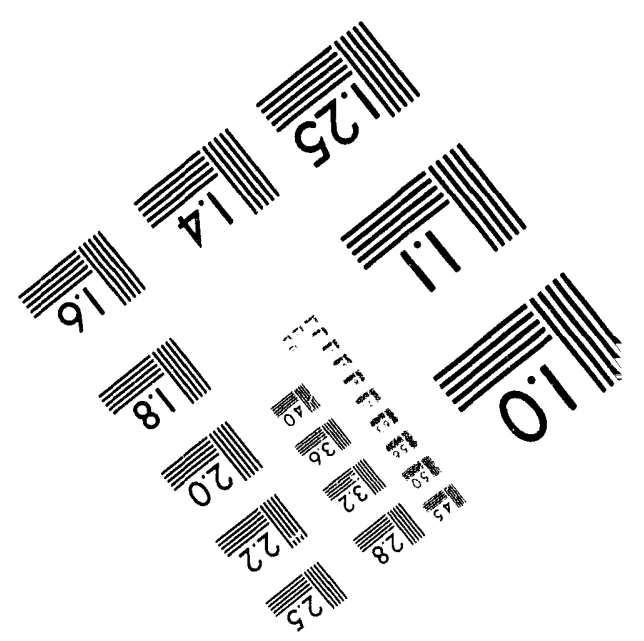



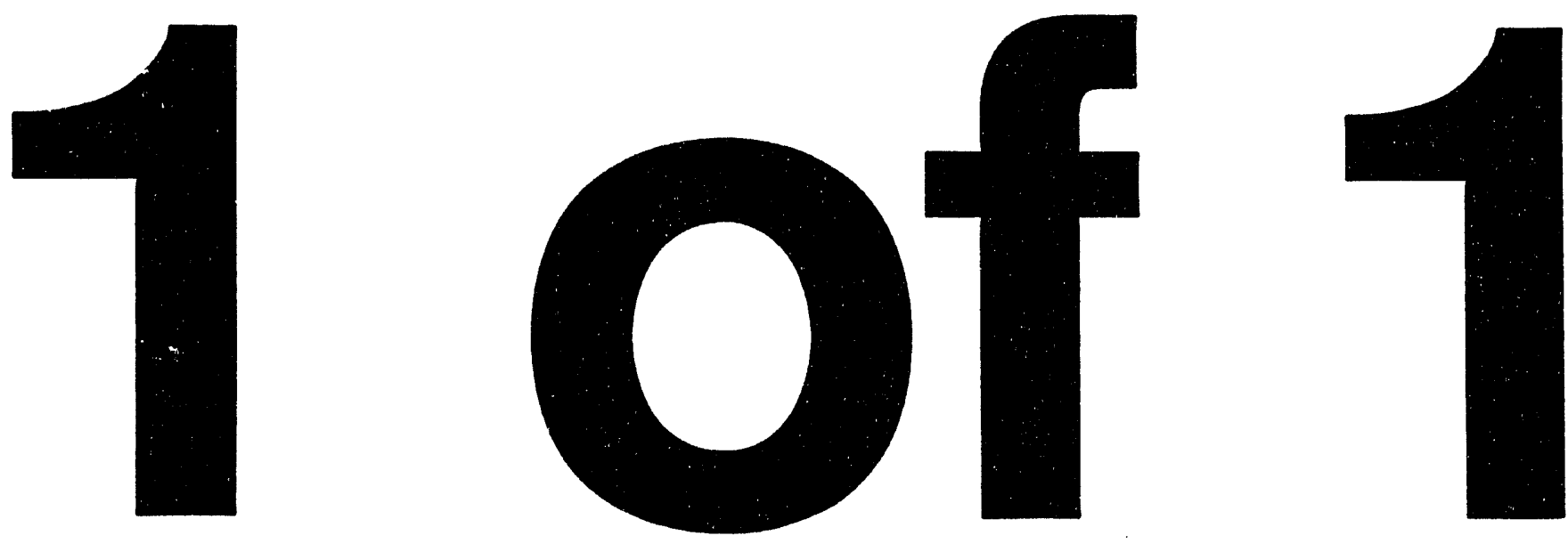


\section{DECLLSSFFED (CLABSIFICATION)}

\section{GENERAL ELECTRIC}

HAMFOND ATOMIC PRODUCTE OPERATION - RICMLAND, WABHINGTON

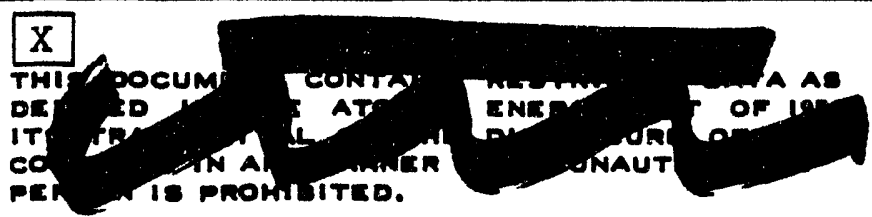

OTHER OFFICIAL CLADeifico IMFORMATION

THIS MATERIAL CONTAINE INFORMATION AFFICTING THE MATIOMAL DEFENSE OF THE UNITED STATES WITHIN THE MEANING of THE ESPIONACE LAWE. TITLE 18, U. S. C., SECS. THS AND TSA, THE TRANEMISEION ON REVELATION OF WHICH IN ANY MANNER TO AN UNAUTHONIzED PERSON IS PROHIEITED GY LAW.
TITLE

FINAL REPORT - PRODUCTION TEST IP-745 HALF-PLANT VAIIDITY TEST

\section{AUTHOn}

J. W. Frymier

May 20, 1965

DOCUMENT NO.

RL-REA-2108

SERIES AND COPY NO.

$$
\text { . }
$$

DATE

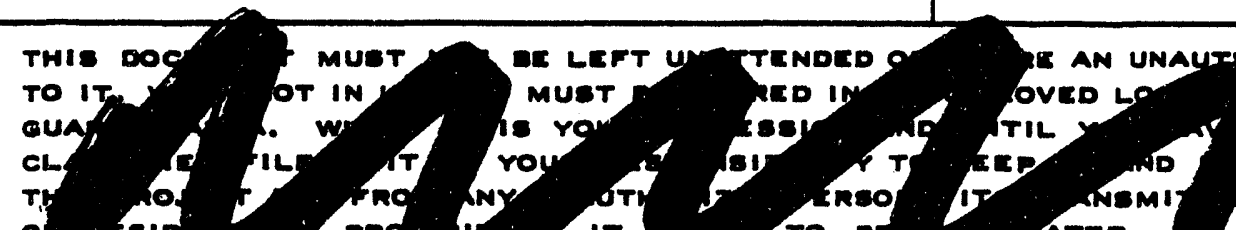

of

Pne

OETAIN THI nROM $T$ TO BION IN THE BPACE Hin NIDED DELOW.

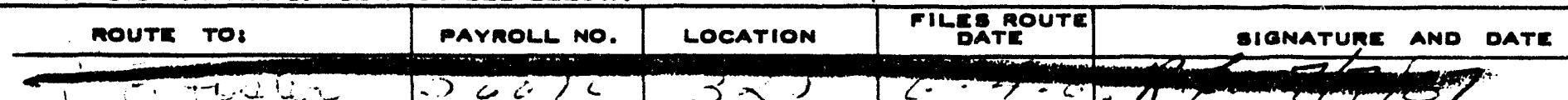

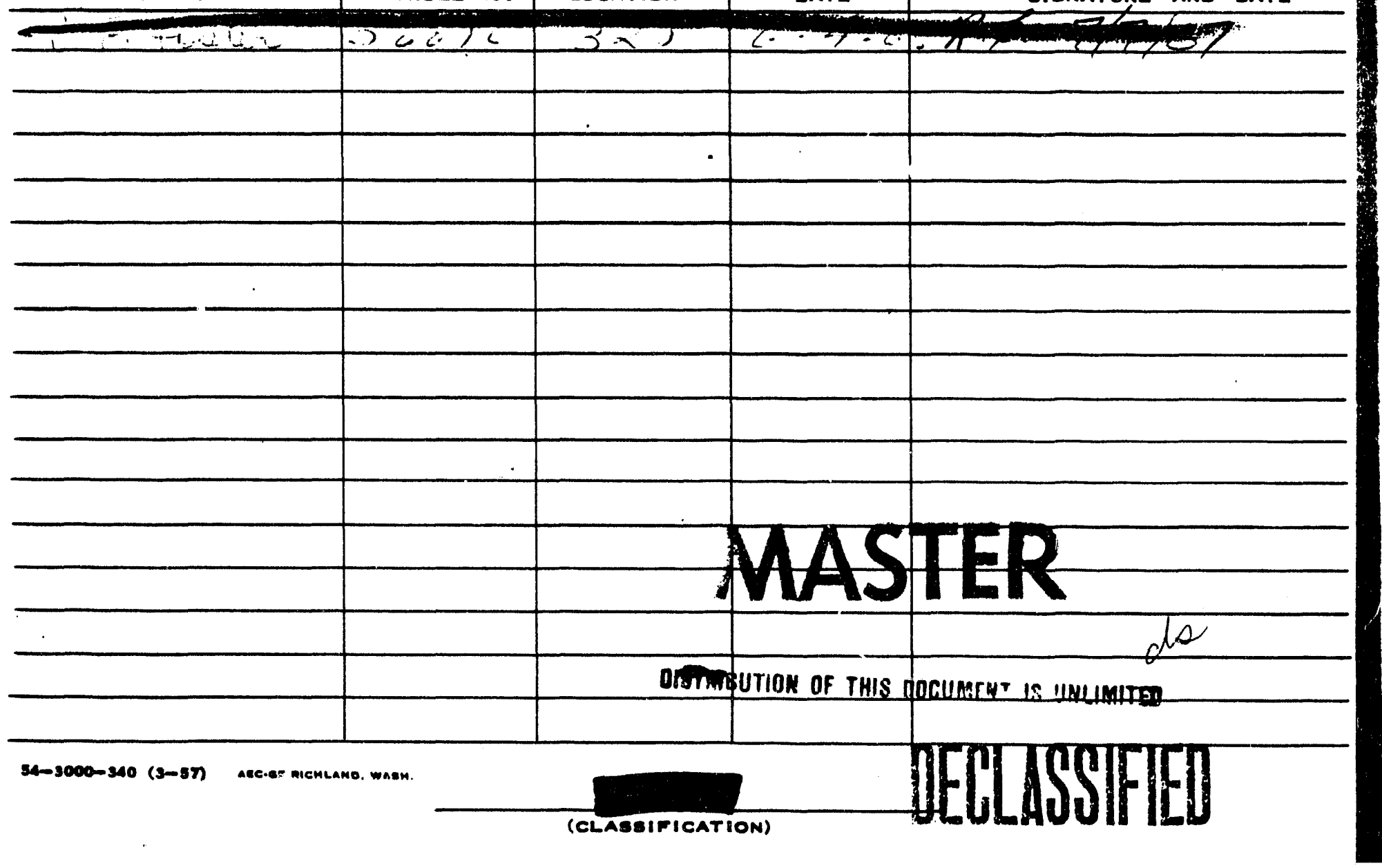


This document classifled by:
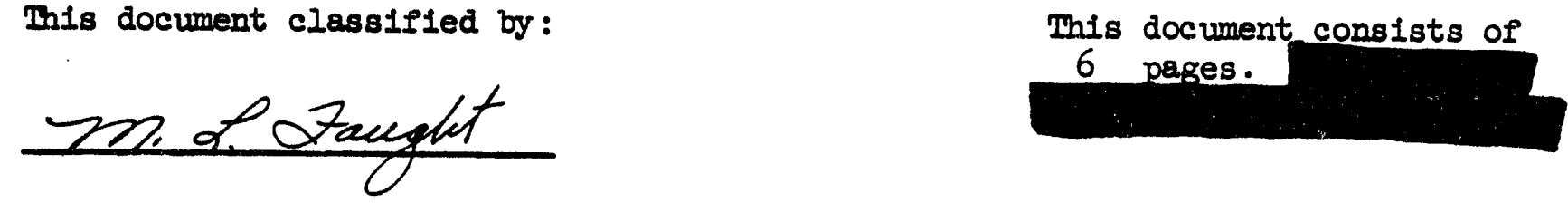

May 20, 1965

FINAL REPORT - PRODUCIION THST IP-745

HAIF-PLANT VALIDITY THST

\section{Distribution}

1. RLOO-AEC - Attn:

2. RLOO-AEC - Attn:

3. RIOO-AEC - Attn:

4. RLOO-AEC - Attn:

5. T. W. Ambrose

6. J. T. Baker

7. J. W. Baker

8. F. B. Barker

9. R: S. Bell

10. I. S. Cave

11. M. A. Clinton

12. R. G. Glough

13. R. B. Crum

14. M. I. Feught

15. E. J. F1lip

16. G. Florelli

17. R. F. Foster - B/NW

18. J. W. Frymier

19. R. G. Geler

20. O. H. Greager

21. A. B. Greninger

22. C. II. Gross

23. I. D. Gustafson

24. R. B. Hall - B/NW

25. A. K. Hardin

26. C. E. Harkins

27. H. W. Heacock
C. D. Corbit

R. I. PIum

R. B. st. Jcin

C. N1. Zangar

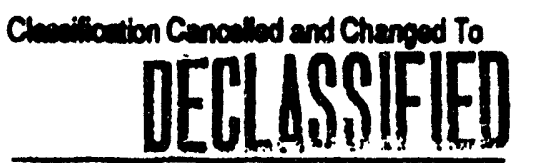

B Autority of DS Lewis CG-NMP-1, 4-28-44 B) Bithanson, 5-16-94

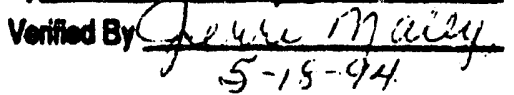

28. D. I. Hirschel

29. P. C. Jerman

30. R. T. Jessen

31. E. R. Keplinger

32. R. J. King

33. A. R. Maguire

34. W. W. MeIntosh

35. J. C. MeIaughlin

36. R. W. McMilcheel

37. S. L. Nelson

38. J. M. Nielsen - B/NW

39. R. W. PItman

40. R. W. Reid

41. R. B. Richmen - B/NW

42. O. C. Schroeder

43. W. B. Silker - B/NW

44. R. E. Spicka

45. R. E. Thomes

46. C. J. Touh111 - B/NW

47. J. D. Turner

48. A. P. Vinther

49. F. F. VIacil

50. L. R. Wallis

51. G. W. WeIIs

52. 700 Files

53. Record Center
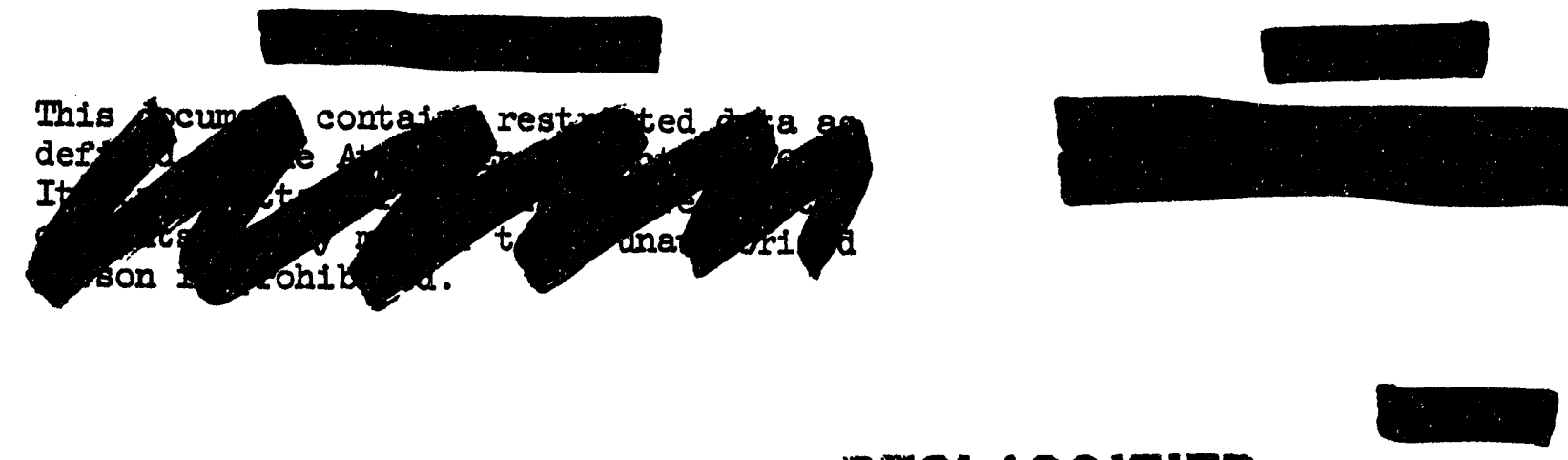
May 20, 1965

FINAL RFPORT - PRODUCTION TEST IP-745 EALF-PLALIT VAITDITY THEST

\section{INIRODUCIIION}

Half-plant production tests have been used for many years to evaluate changes in water treatment processes. Since some conjecture existed regarding the validity of this test concept, it was decided to employ a tracer element. Bromine was chosen as the tracer element due to its absence in raw water, the short half life of Its radionuclides, and Its compatibllity. as a potable water treatment chemical.

The parent production test was run for four days, but the scatter in the data indicated equilibrium had not been reached and conclusions could not be made. The test supplement was run for a period of 12 days.

\section{SUMMARY}

The test data show that an average cross flow of $7.6 \%$ is experienced, as measured in the reactor rear riser, when a reasonably balanced pumpling system is maintained.

Operating experfences at $D$ and $F$ Reactors during the early part of 1965 further confirm these facts. Excessive f1lm bulld-up occurred in both instances on plant halves. A distinct demarkation IIne was experfenced between vertical rows 73 and 74 , as measured by front face Panellit pressure increases.

\section{DISCUSSION}

Bromine Addition and Water Flow System

This test was run in $\mathrm{H}$ Reactor Plant during the perlods of February 2-5, 1965, (original) and fram April 6-20, 1965 (supplement).

$\mathrm{Na} \mathrm{Br}$, grade NF, in an average amount of $0.3 \mathrm{ppm}$ was added to the east (near) bauxite feed machine at 183-H. Grab water samples were obtained daily at 7:30 AM from the near and far reactor rear risers. These samples were forwarded to B-NW 300 Area Laboratorles for activated bromine analysis. Calculations were then made of the percentage of cross-mixing.

The water flow systems from 183 raw water inlet to the reactor front face were operated as 1dentical split systems, w1th the exception that the 183 filtered water $100 \mathrm{p}$ remained open between 183 and 190. The valving arrangement in this loop does not permit an equal division of flow. Balanced pump units, however, were maintained on this system.

A slight unbalanced flow condition existed in the process water system from 190 to the reactor front face. 


\section{0-H Bullding (Supplement Test)}

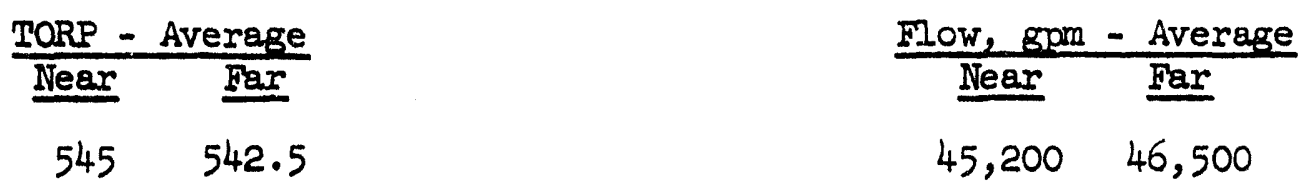

This condition can be attributed to slight differences in pumping and piping characterlstics, since all cone valves were operated in the fully open position.

Rear Riser Br Anelysis (1)

क Cross-Mixing

\section{Original Test}

$\begin{array}{cr}2 / 2 / 65 & 19.7 \\ 3 & 9.2 \\ 4 & 15.3 \\ 5 & 5.8\end{array}$

Supplement Test

$\begin{array}{ll}4 / 11 / 65 & 9.4 \\ 12 & 8.1 \\ 13 & \text { Down } \\ 14 & \text { Down } \\ 15 & 7.1 \\ 16 & 7.0 \\ 17 & 6.7 \\ 18 & 6.4 \\ 19 & 6.9 \\ 20 & 9.2\end{array}$

(1) Progress Report, W. B. Silker, period ending May 15, 1965. 


\section{F Reactor Plant}

On January 1, 1965, at 183-F Bullding, an underwater sulfurlc acid feed line developed a leak. This caused a major part of the acid being fed to the west (far) half to be channeled through no. 6 basin. The resulting water coagulation imbalance created a rapid film bulld-up on the far side of $F$ Reactor.

The attached front face Panellit map indicates those channels in which the pressure increased 15 or more psi above base. A distinct split in film build-up is observed between vertical rows 73 and 74 , which is the dividing line of the reactor. The water system upstream of the process water cross tie valve in 105 Valve Pit was operated as an integral plant; however, balanced flows were maintained on each plant half.

\section{Reactor Plant ${ }^{(2)}$}

Sodium sillcate addition was started to the far half of D Reactor on January 15, 1965, as authorlzed by Production Test No. IP-728. A Panellit monitoring program was established on the test and control side to establish pressure changes from base. A rapld film build-up was experienced on the test half. During the first 60 days, the test side fringe Thoria channels increased a total of $25 \mathrm{psig}$ while the control side remained at zero.

A total increase of $5 \mathrm{psig}$ wis similarly observed in the test side core Thoria channels during the first 25 days, while the control side core Thorla channels remalned at zero. The film bulld-up split occurred between vertical rows 73 and 74 .

During the period of April 1-7, 1965, the front TORP was unbalanced by 2 psi. This caused the flow split to shift from the customary vertical rows 73 and 74 to vertical rows 72 and 73 . 190 Tank Inlet and outlet valves were closed during the test.

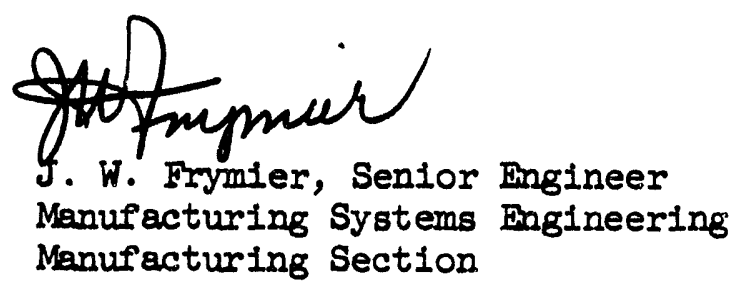

JWF : bdt

(2) Personal Correspondence, D. L. Hirschel to J. W. Frymier, May 12, 1965. 


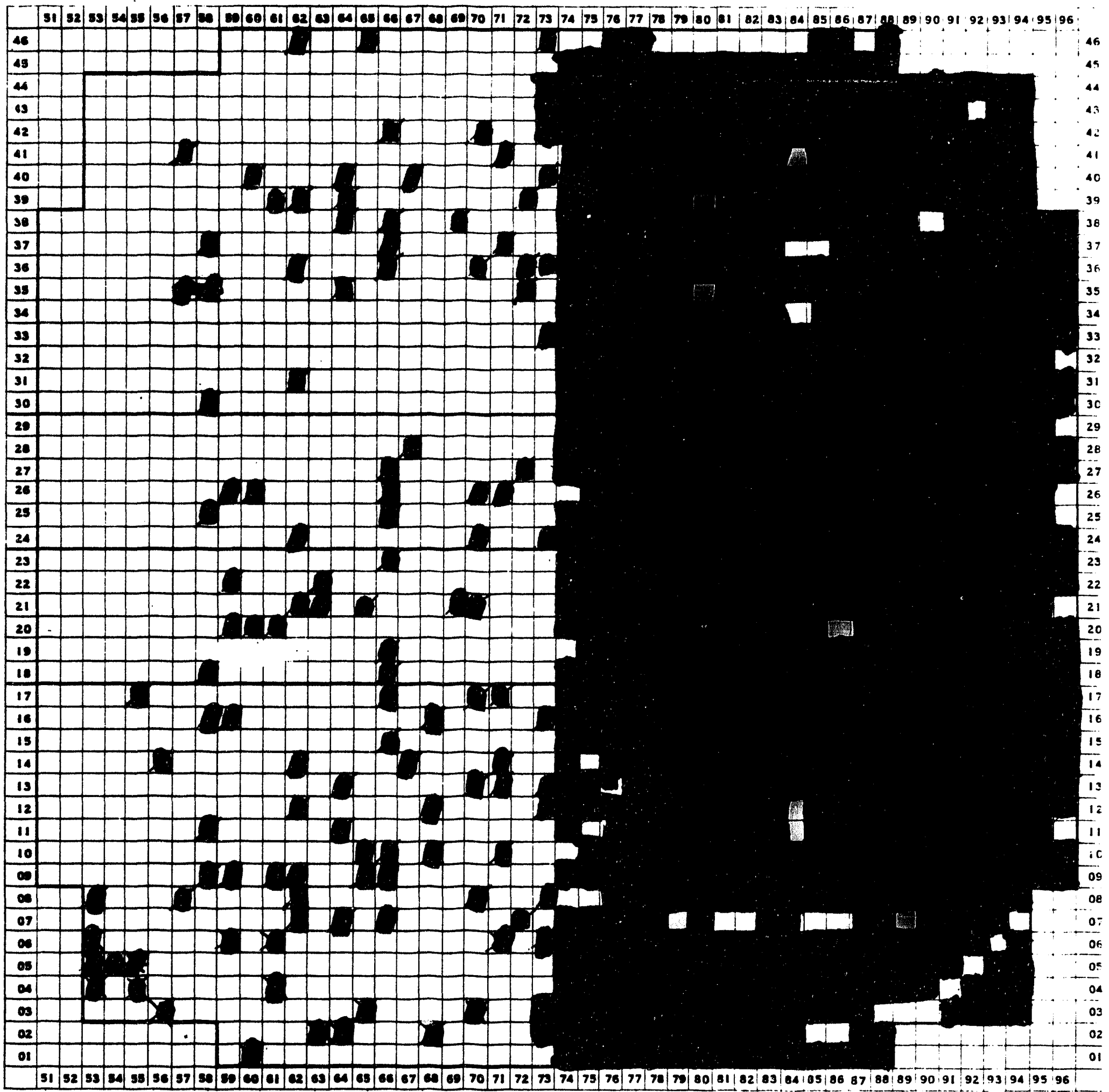

F Reactor Froni Fuse libl

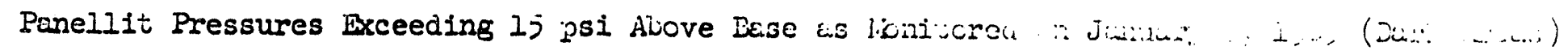




\begin{tabular}{|c|c|c|c|c|c|c|c|c|c|c|c|c|c|c|c|}
\hline \multirow[b]{3}{*}{ Date } & \multirow[b]{3}{*}{ Time } & \multicolumn{7}{|c|}{$105-\mathrm{H}$} & \multicolumn{5}{|c|}{$190-\mathrm{H}$} & \multirow{2}{*}{\multicolumn{2}{|c|}{$\begin{array}{l}\text { Na Br Feed } \\
\text { Daily Avg-ppm }\end{array}$}} \\
\hline & & \multicolumn{2}{|c|}{ TORP-psi } & \multirow{2}{*}{$\begin{array}{l}\text { Water } \\
\text { Process }\end{array}$} & \multirow{2}{*}{$\begin{array}{l}\text { Flow-gpm } \\
\text { Thermal } \\
\text { Loop }\end{array}$} & \multicolumn{2}{|c|}{$\begin{array}{l}\text { Exit Temp. } \\
\text { Bulk- }{ }^{\circ} \mathrm{C}\end{array}$} & \multirow{2}{*}{$\begin{array}{l}\text { Br Activation } \\
\text { Analysis } \\
\text { o Cross Flow }\end{array}$} & \multicolumn{2}{|c|}{ TORP-psi } & \multirow{2}{*}{$\frac{\text { Water }}{\text { Near }}$} & \multicolumn{2}{|c|}{ Flow-Pumps-gpm } & & \\
\hline & & Near & Far & & & Near & Far & & Near & Far & & Far & Ibtal & E(Near) & W(Far) \\
\hline $4 / 6 / 65$ & $7: 30 \mathrm{~A}$ & 545 & & 91.800 & 1246 & $(11) 65.2$ & $(1))_{62,1}$ & & & 543 & $y_{15} \mathrm{con}$ & $\mathrm{Bu}_{\mathrm{l}} \mathrm{7 \textrm {m }}$ & & & \\
\hline 7 & $7: 30 \mathrm{~A}$ & 545 & 540 & 91,800 & $\begin{array}{l}1<40 \\
1246\end{array}$ & 979.0 & 143.2 & No Sample & $\begin{array}{l}347 \\
545\end{array}$ & $\begin{array}{l}543 \\
543\end{array}$ & $a 45,900$ & $\left\{\begin{array}{l}4,700 \\
46,200\end{array}\right.$ & $\begin{array}{l}90,600 \\
91,200\end{array}$ & $\begin{array}{l}0.23 \\
0.24\end{array}$ & 0 \\
\hline 8 & $7: 30 \mathrm{~A}$ & 545 & 540 & 92,000 & 1246 & 79.5 & 75.5 & No Sample & 545 & 543 & 45,200 & 46,500 & 91,700 & 0.28 & 0 \\
\hline 9 & $7: 30 \mathrm{~A}$ & 545 & 540 & 92,000 & 1240 & $79 \cdot 9$ & 76.1 & Contaminated & 545 & 543 & 45,200 & 46,500 & 91,700 & 0.31 & 0 \\
\hline 10 & $7: 30 \mathrm{~A}$ & 545 & 540 & 92.000 & 1270 & 707 & 712 & Sample & & & & & & & \\
\hline$+\infty$ & & 347 & 240 & Ye,000 & 1210 & $19 \cdot 1$ & 14.2 & $\begin{array}{l}\text { Wontaminated } \\
\text { Sample }\end{array}$ & 345 & 543 & 45,200 & 46,500 & 91,700 & 0.31 & 0 \\
\hline 11 & $7: 30 \mathrm{~A}$ & 545 & 540 & 92,000 & 1240 & 79.2 & 74.8 & 9.4 & 545 & 543 & 45,200 & 46,500 & 91,700 & 0.31 & 0 \\
\hline 12 & $7: 30 \mathrm{~A}$ & 5451 & 540 & 92,000 & 1210 & 80.7 & 75.5 & 8.1 & 543 & 541 & 45,200 & 46,500 & 91,700 & 0.30 & 0 \\
\hline $\begin{array}{l}13 \\
14\end{array}$ & $\begin{array}{l}7: 30 \mathrm{~A} \\
7: 30 \mathrm{~A}\end{array}$ & $\begin{array}{l}\text { Do } \\
\text { Do }\end{array}$ & $w n$ & & & & & & & & & & & & \\
\hline 15 & $7: 30 \mathrm{~A}$ & 545 & 537 & 91,800 & 1260 & ${ }^{1} 68.2$ & 64.5 & 7.1 & 545 & 542 & $q_{45,200}$ & 46,300 & 91,500 & 0.33 & 0 \\
\hline 16 & $7: 30 \mathrm{~A}$ & 545 & 535 & 92,000 & 1210 & 79.0 & 77.2 & 7.0 & 545 & 542 & 45,200 & 46,500 & 91,700 & 0.29 & 0 \\
\hline 17 & $7: 30 \mathrm{~A}$ & 545 & 535 & 92,000 & 1211 & 78.7 & 77.0 & 6.7 & 545 & 542 & 45,200 & 46,500 & 91,700 & 0.33 & 0 \\
\hline 18 & $7: 30 \mathrm{~A}$ & 545 & 535 & 92,000 & 1246 & 79.0 & 76.8 & 6.4 & 545 & 542 & 45,200 & 46,500 & 91,700 & 0.35 & 0 \\
\hline 19 & $7: 30 \mathrm{~A}$ & 545 & 535 & 92,000 & 1211 & 79.5 & $77 \cdot 3$ & 6.9 & 545 & 542 & 45,200 & 46,500 & 91,700 & 0.30 & 0 \\
\hline 20 & $7: 30 \mathrm{~A}$ & 545 & 535 & 92,000 & 1246 & 79.2 & 77.2 & 9.2 & 545 & 542 & 45,200 & 46,500 & 91,700 & 0.29 & 0 \\
\hline Ave & erage & & & & & 77.9 & 75.0 & 7.6 & & & 45,200 & 46,500 & & 0.30 & \\
\hline & & & & & & 4 & & & & & & & & & \\
\hline & & & & & & & & & & & & & & & \\
\hline
\end{tabular}

(I) Excluded from average. 

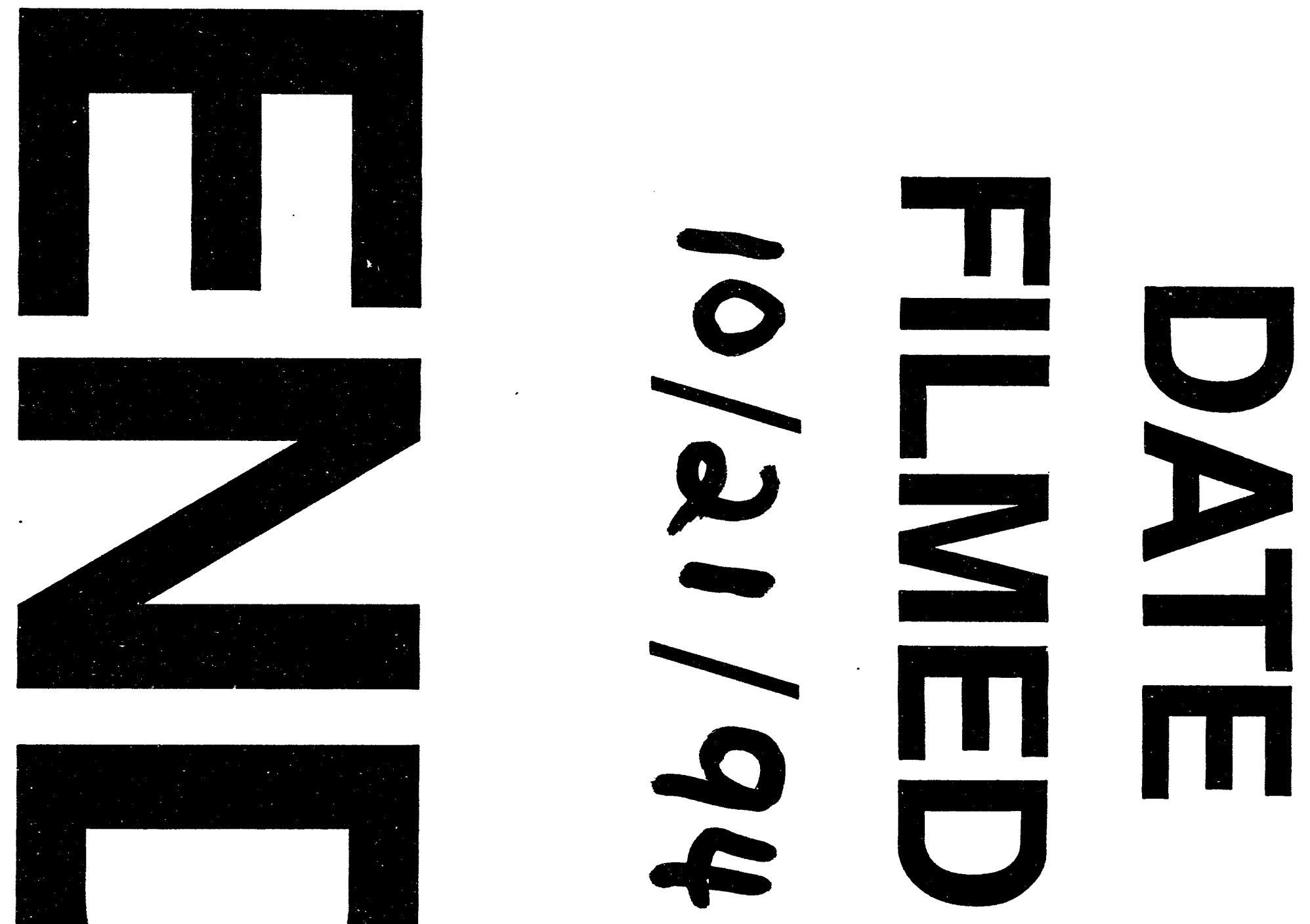
